\title{
Meristem Culture and its Stigmasterol Content of Purwoceng (Pimpinella pruatjan Molk.) for Agricultural Sciences
}

\author{
Totik Sri Mariani \\ Biosciences and Biotechnology Research Center, \\ Bandung Institute of Technology, Ganesha 10 Bandung 40132. Indonesia \\ Sukrasno \\ School of Pharmacy, Bandung Institute of Technology, \\ Ganesha 10. Bandung 40132. Indonesia.
}

\begin{abstract}
Purwoceng (Pimpinella pruatjan Molk.) is a legend plant used for increasing stamina by Kings in Java island, Indonesia. Purpose of this study was to perform meristem culture and detected its stigmasterol by thin layer chromatography (TLC). Our result show that meristem culture could be propagated and grew into plantlet. After extracting intact acclimatized plant derived from meristem culture by hexane, we could detect stigmasterol by TLC. For suggestion, our extraction and TLC method could be used for detecting stigmasterol in others plant. The meristem culture method would be useful for creating clone and virus free plant as added value in agricultural sciences.
\end{abstract}

Keywords - Purwoceng, meristem culture, extraction, Thin Layer Chromatography

\section{INTRODUCTION}

Purwoceng is one of the medicinal plants native to Indonesia and is much sort after and needed by the drug industry because of its powerful medicinal and high economic value [1].

As Purwoceng is a high altitude endemic species, it is currently cultivated on a limited area in Dieng plateau [2]. Due to the popularity and high demand for this medicinal plant, it is urgent to develop a mass propagation system through the meristem culture method.

The added value of using the meristem culture method is its ability to eliminate virus infection in plants. In addition, it could be mass propagated easily by using MS medium [3] supplemented with 0.5 ppm Benzyl Adenine Purine (BAP).

Purpose of this study is initiating and establishing an in vitro culture system capable of mass culture of Purwoceng. This involves the propagation and acclimatization of the plantlets. To the best of our knowledge, there is currently no report on the meristem culture of Purwoceng. In addition, the purpose is developing an efficient extraction and analysis method for stigmasterol by Thin Layer Chromatography (TLC).

\section{MATERIAL AND METHODS}

\section{A. Meristem culture and multiplication}

The explant (shoot) was surface sterilized by $96 \%$ alcohol for 30 second and $20 \%$ chlorox for 3 minutes. Then, the explant was washed by sterile water four times. The scale of the shoot was opened under stereomicroscopy until 0.2$0.5 \mathrm{~mm}$ shoot mersitem was obtained. The shoot meristem was cultured on initiation media MS [3] containing $1 \mathrm{gl}$ active charcoal for two weeks. Thereafter, shoots were subcultured on MS media supplemented with $0.5 \mathrm{mg} / \mathrm{l}$ BAP and $0.025 \mathrm{mg} / \mathrm{l} \alpha$ - napthaleneacetic acid (NAA) for multiplication. For further propagation, the shoot was subcultured on MS media with B5 vitamin supplemented with $0.5 \mathrm{mg} / \mathrm{l} \mathrm{BAP.}$

\section{B. Acclimatization}

After plantlet developing, the plants were acclimatized by covering them with plastic bag. After one month, the plastic bag was opened. 


\section{Extraction}

A sample was dried in an oven at $40^{\circ} \mathrm{C}$. The drying sample was put into $30 \mathrm{ml}$ of hexane and refluxing for three hours. A result of reflux was filtered and storing in an amount of $20 \mathrm{ml}$. The procedure above was repeated four times to obtain the amount of $80 \mathrm{ml}$. Thereafter, filtrates were collected. The filtrates were then evaporated until seen viscous.

\section{Thin Layer Chromatography (TLC)}

A filtrate was spotted on a TLC. The TLC was then put into a chamber containing developing solution. The developing solution is Hexane: Acetic ethyl = 8:2. Subsequently, a TLC was sprayed by $\mathrm{H}_{2} \mathrm{SO}_{4}$ and observing under UV $366 \mathrm{~nm}$.

\section{RESULT AND DISCUSSION}

\section{Meristem culture}

Initially, we performed a meristem culture to obtain a clone of P. pruatjan (Fig. 1A) followed by shoot culture of $P$. pruatjan obtained by shoot propagation in MS medium with Gamborg B5 vitamin supplemented by $0.5 \mathrm{ppm}$ of BAP. After one month of culture, 100 plantlets of $P$. pruatjan are obtained in good condition with no indication of disease (Fig. 1B). This shows the advantage of meristem culture. Roots were developing from the shoot (Fig. 1C) without requirement to be subcultured onto rooting medium, because the shoots derived from meristem culture. The roots grew rapidly from the meristem explants to the bottom of the flask. Roots are important part of the plant since the metabolites such as stigmaterol is synthesized in the roots [4].

The plantlets were then subjected into sterilized soil for acclimatization. Following the process, the plantlets were growing well (Fig. 1D). In the end, 95\% of 300 plants survive the acclimatization (Fig. 1 E). Intact acclimatized growing plants were cleansed first with water and later extracted by using hexane, ethanol, and methanol. TLC analysis was then carried out.

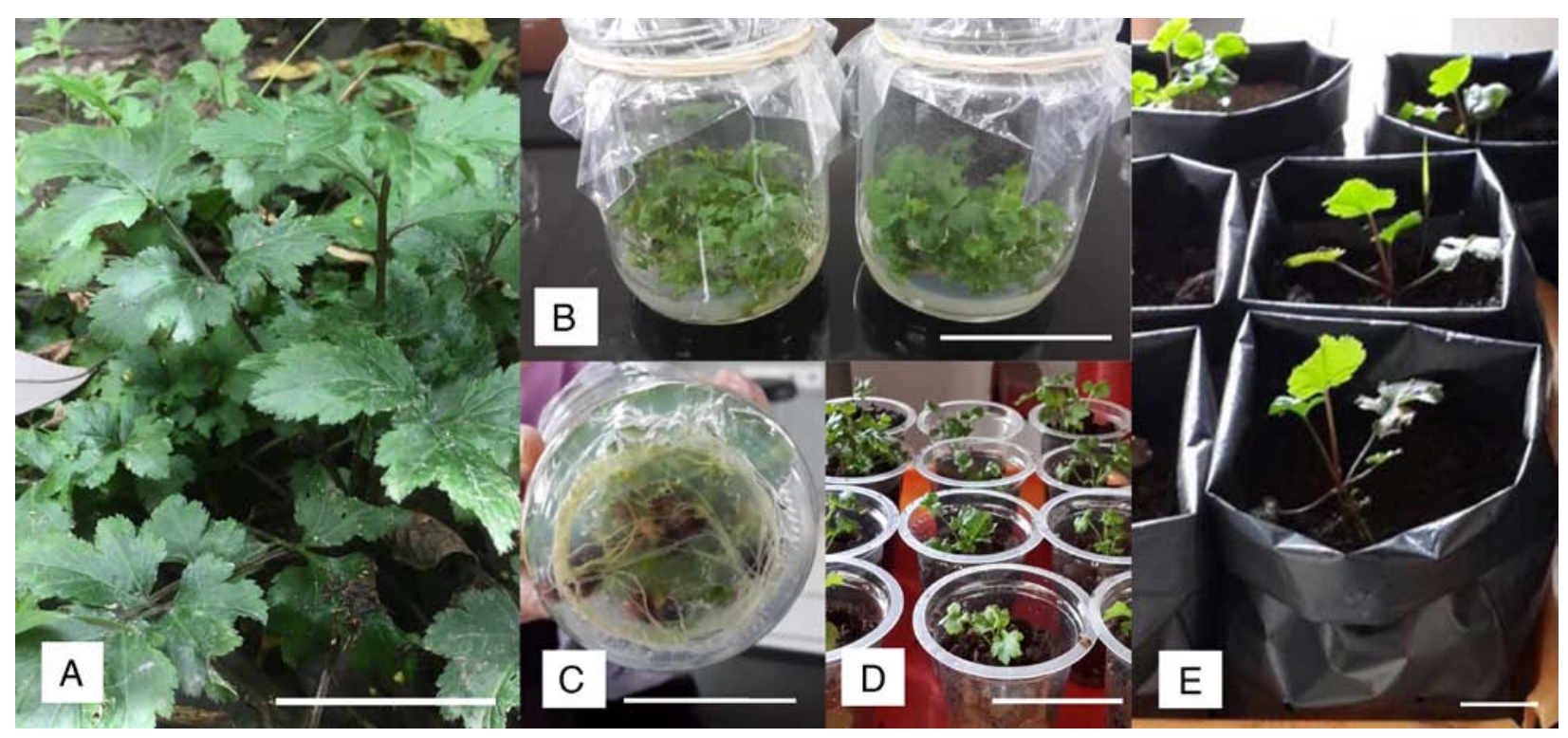

Figure 1. Purwoceng or $P$. pruatjan mature living plant (A), culture of $P$. pruatjan (B) shoots developed a massive rooting system shown in the bottom of the flask (C). The final stage of culture, where $P$. pruatjan plant under earlier stage of acclimatization in the plastic cups (D) and later stage in polybags prior to extraction (E). Scale bar $=5 \mathrm{~cm}$. 


\section{Stigmasterol extraction and TLC}

Extracted plant sample using hexane, ethanol, and methanol shows the bands that indicate the existence of stigmaterol of cultured P. pruatjan plant in similar positions as the standardized one (Fig. 2). However, the bands have different intensities on each sample, indicating that ethanol and methanol provides better results of extraction than hexane. Previous studies are mostly found to extract $P$. pruatjan using ethanol and methanol [5,6,7]. Stigmasterol is soluble in usual organic solvent and including benzene, ethyl ether, and ethanol [8,9] and it's practically insoluble in water as its solubility is $1.12 \times 10^{-15} \mathrm{mg} / \mathrm{l}$ at $25^{\circ} \mathrm{C}[10]$.

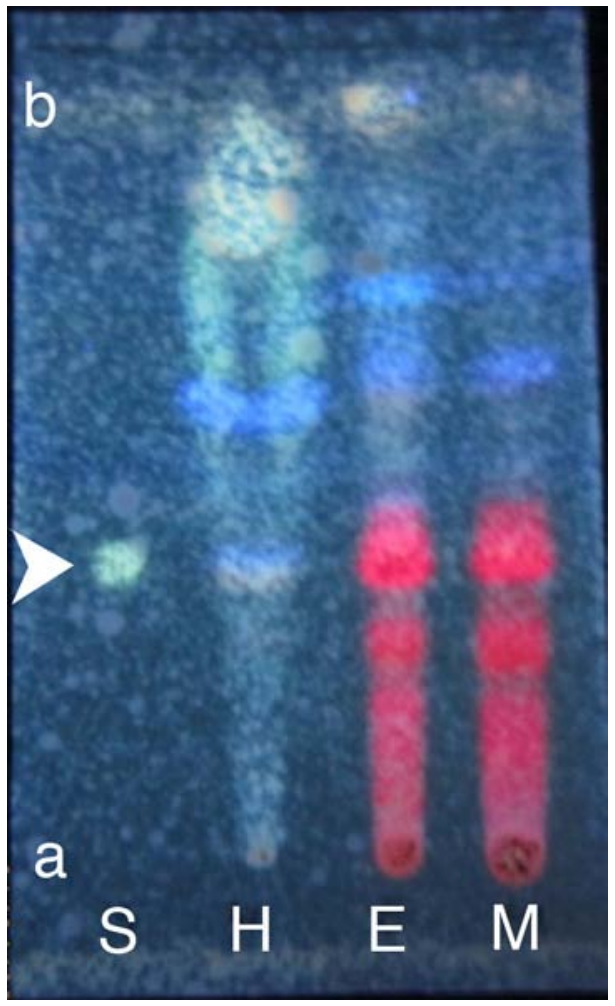

Figure 2. Thin layer chromatography (TLC) result. Showing the baseline (a) and solvent front (b). White arrow indicates the position of stigmasterol bands as the solvent carried from bottom to top: standardized stigmasterol of $P$. pruatjan (S) within the TLC plate compared to the plant extract using hexane $(\mathrm{H})$, ethanol $(\mathrm{E})$, and methanol $(\mathrm{M})$.

\section{IV.CONCLUSION}

Conclusively, meristem culture of $P$. pruatjan provides a promising way for mass propagation with stable genetic material and pathogen free plants. According to this study, the cloned plant could produce stigmasterol as the mother plant. This meristem culture on $P$. pruatjan will be a big potential for agricultural science, especially in studies of plant metabolites production with good quality and also to contribute to this plant conservation in the wild. As this plant is including to the endangered plant, the result of mass propagation (300 plants within 3 months culture and acclimatization) will be useful to plant them in the Dieng plateau. . It is suggested of using this method in the field of agricultural sciences.

\section{ACKNOWLEDGEMENT}

We acknowledged Indonesian Ministry of Research and Education for supporting this research. We thankful to Mrs. N. Heni Hanurati and Mr. A. Syahrian Siregar for assisting in tissue culture, Mrs. Isna Mulyani for helping in phytochemistry analysis. We also acknowledged Mr. Adhityo Wicaksono M.Sc. for revising the manuscript. 


\section{REFERENCES}

[1] Widayat, T.A., Soetarto, E.S. 2012. Isolation of endophytic bacteria from Purwoceng (Pimpinella alpine Kdeevess.). Health Science Indones. 1: 31-36

[2] Ajijah, N., Darwati, I., Yudiwanti and Roostika. 2010. Effect of incubation temperature on growth and development of Purwoceng (Pimpinella pruatjan Molk.) somatic embryo. Jurnal Penelitian Pertanian Tanaman Industri,16 (2): 56-63

[3] Murashige, T. and Skoog, F. 1962. A revised medium for rapid growth and bioassays with tobacco tissue cultures. Plant Physiol. 15: 473497

[4] Nurhasnawati, H. 2002. Isolation and characterization of stigmaterol in Purwoceng (Pimpinella alpine Molk.) Undergraduate thesis. FMIPA. UNDIP.

[5] Usmiati, S. and Yuliani, S., 2014. Efek Androgenik dan Anabolik Ekstrak Akar Pimpinella alpina Molk (Purwoceng) pada Anak Ayam Jantan. JITV, 19(3). pp.744-755 (In Indonesian).

[6] Nasihun, T., 2009. Pengaruh Pemberian Ekstrak Purwoceng (Pimpinella alpina Molk) terhadap Peningkatan Indikator Vitalitas Pria Studi Eksperimental pada Tikus Jantan Sprague Dawley. Sains Medika, 1(1), pp.53-62 (In Indonesian).

[7] Taufiqqurrachman, T., 1999. Pengaruh Ektrak Pimpinella alpina Molk.(purwoceng) DAN AKAR Eurycoma longifolia Jack.(pasak bumi) Terhadap Peningkatan Kadar Testosteron, Lh Dan Fsh Serta Perbedaan Peningkatannya Pada Tikus Jantan Sprague Dawley (Master thesis, Program Pendidikan Pasca sarjana Universitas Diponegoro) (In Indonesian).

[8] Lide, D.R., 2007. Handbook of Chemistry and Physics $88^{\text {th }}$ ed. CRC Press, Boca Raton. pp.3-462.

[9] Lewis Sr., R.J., 2007. Hawley's Condensed Chemical Dictionary $15^{\text {th }}$ ed. John Wiley \& Sons, Inc. New York. p.1179.

[10] PubChem, 2016. Stigmasterol. https://pubchem.ncbi.nlm.nih.gov/compound/Stigmasterin (date accessed: October 17th, 2016). 